\section{THE WABASH CENTER}

JOURNAL on TEACHING

\title{
From Lament to Advocacy: Black Religious Education and Public Ministry
}

\author{
Anne E. Streaty Wimberly, Annie Lockhart-Gilroy, \\ Nathaniel D. West, editors \\ Nashville, TN: Wesley's Foundery Books, 2020 ( $x x+239$ pages, ISBN 978-1-945-93574- \\ 9, \$39.99)
}

\section{Reviewed By}

Tracey Lamont

Loyola University, New Orleans

This edited volume emerged from a gathering of Black religious educators at the 2015 Religious Education Association annual meeting in Atlanta, Georgia. They asked the pressing question, "What should we do?" in response to the continual shootings and other violence perpetrated on unarmed black men, women, and children; how can religious educators address the magnitude of challenges facing Black communities (xii, xiv)? Given our polarized, racially unjust societyquick to separate religion and faith from politics and the public sphere-this book could not be timelier.

The text engages the reader through interdisciplinary scholarship across multiple lines of inquiry, from Joseph Crocket's essay on the intersection of critical pedagogy and Black Lives Matter, Anne Streaty Wimberly's chapter on womanist theology and formation, Mary Young's curricular methods "for learning and acting community" (82), a pedagogy of what Nathaniel West names "Prophetic Inquiry" drawn from Afrocentric practices of ubuntu and ujima (51), to Sarah Farmer's "macrolevel approach to prison ministry that explores core pedagogical commitments" through religious education (140). Each chapter illustrates one or more of the five components of justice education, which, as Wimberly describes, includes a "holistic orientation" of relational, physical, psychological, economic/vocational, and spiritual characteristics (xxv-xxvi). Through this, the authors explore how religious educators can teach and learn from lament, black identity development, and advocacy.

Annie Lockhart-Gilroy, in her epilogue, states clearly just how important it is for religious educators to engage in public ministry. She writes, "whether explicitly or not, public spaces present their own curriculum" and too often this curriculum, as Nancy Lynne Westfield notes, teaches Black people "to be complacent and to participate in their own oppression because of the identities we embody" (231). This volume provides religious educators with what Lockhart-Gilroy calls "a counter curriculum-a curriculum that counters society's curriculum by first calling out the lie that it is, lamenting the messages we have internalized, and then countering with public advocacy centered in religious education" (232).

This work advances the field by placing religious education in critical dialogue with public ministry and presents important theoretical frameworks and practical pedagogical approaches for religious educators to envision their praxis as a public ministry for the transformation of society. The authors in this volume illuminate the history, ancestry, culture, heritage, and lived experiences of Black religious educators, individuals, faith communities, and, in particular, contemporary Black youth (Richelle White and Cynthia Stewart's essays) by making it clear that faith communities have a vital role to play in teaching young people how to be leaders in their communities (xv).

The essays in From Lament to Advocacy are important for graduate and doctoral students engaging in pastoral ministry, social justice, public theology, and religious education, and are equally as important for scholars in religious education as a resource filled with dynamic pedagogies and curricular approaches that help address systemic racism and the challenges facing Black communities. As such, this edited volume challenges all ministry leaders and religious educators to consider the implications of their praxis in a world in need of reconciliation and healing.

272 2021; 2:1 272-272 The Wabash Center Journal on Teaching

This work is licensed under a Creative Commons Attribution-NonCommercial 4.0 International License 